\title{
Analgesic and Anti-inflammatory Activity of Roxithromycin and Erythromycin, Alone and in Combination with Ibuprofen: An Animal Study
}

\author{
Akash A Khobragade $^{1 *}$, Sadiq B Patel ${ }^{2}$, Rupesh R Pophale ${ }^{1}$, \\ Vallish BN ${ }^{3}$, Snehal P Kosale ${ }^{4}$ \\ ${ }^{1}$ Assistant Professors, ${ }^{2}$ Professor and Head, ${ }^{3}$ PG student (JR-3), Department of Pharmacology; ${ }^{4}$ Final MBBS Student \\ Grant Medical College \& Sir JJ Group of Hospitals, Byculla, Mumbai- 400008
}

\begin{abstract}
Background: Several in-vitro, animal and clinical studies have reported anti-inflammatory activity of macrolides. Antiinflammatory properties of macrolides form the basis for their experimental use in airway inflammatory and infective conditions like asthma

Materials and Method: After animal ethics committee approval, the anti-inflammatory and analgesic potentials of erythromycin $(40 \mathrm{mg} / \mathrm{kg})$ and roxithromycin $(20 \mathrm{mg} / \mathrm{kg})$ were evaluated in carrageenan-induced rat paw edema model and rat tail flick model respectively, in comparison and combination with ibuprofen $(100 \mathrm{mg} / \mathrm{kg})$ in albino wistar rats.

Results and Interpretation: Both the macrolides were found to have significant anti-inflammatory activity, roxithromycin being slightly more efficacious than erythromycin. Combination with ibuprofen failed to produce improved benefit. Both the macrolides neither showed significant analgesic property alone, nor enhanced analgesic effect of ibuprofen significantly.

Conclusion: The macrolides have shown anti-inflammatory activity and a tendency towards analgesic potential; possible mechanisms are discussed. Further studies are required before any recommendations can be made.
\end{abstract}

Keywords: Analgesic, Animal study, Anti-inflammatory, Erythromycin, Ibuprofen Roxithromycin

\section{Introduction}

Macrolide antibiotics constitute a group of 12 to 16 -membered lactone rings substituted with one or more sugar residues ${ }^{1}$.

Erythromycin, the first macrolide to be described, was first isolated in $1952^{2}$; since then it has established itself as one of the safest antibiotics in use and an effective alternative to penicillin for the treatment of and prophylaxis against Gram positive infections of the skin, soft tissues and respiratory tract, and agent of choice for treating infections caused by Mycoplasma pneumoniae, Bordetella pertussis and Legionella $\mathrm{sp}^{3}$.

Roxithromycin is a semi-synthetic macrolide developed to overcome the limitations of erythromycin like gastric acid lability, low oral bioavailability, poor tissue penetration and short half life $\mathrm{e}^{4}$. It has same antimicrobial spectrum as Erythromycin, and is more potent against Branhmella catarrhalis, Gardnerella Vaginalis and Legionella. It is a good alternative to Erythromycin for respiratory, aural, pharyngeal, nasal, skin, soft tissue and genital infections ${ }^{5}$.

Apart from antibacterial activity, macrolides are documented to have anti-inflammatory actions, and the same has been documented in animal models ${ }^{6}$, as well as in clinical scenarios ${ }^{7-9}$. The anti-inflammatory activity of Roxithromycin and erythromycin are proposed to be independent of Cyclo-Oxygenase-2 (COX 2) inhibition ${ }^{6}$.

The anti-inflammatory properties of macrolides form the basis for their experimental use in bronchial asthma and airway inflammatory and infective conditions ${ }^{10-12}$. However, a cochrane review in 2005 concluded that there is insufficient evidence for the use of macrolides in chronic asthma, and that further studies are required in the same field ${ }^{13}$. Moreover, there is paucity of animal studies done to evaluate the anti-inflammatory and analgesic activities of macrolides in general and of erythromycin and roxithromycin in particular, with proper comparisons with known anti-inflammatory and analgesic agents. Hence, we planned this study with the aims to evaluate the anti-inflammatory and analgesic activity of erythromycin and roxithromycin, alone and in combination, in comparison with the non-selective COX inhibitor Ibuprofen, in Albino Wistar Rats. 


\section{Materials and Methods Study drugs and chemicals}

The test drugs erythromycin and roxithromycin and the standard drug ibuprofen (Arums Pharmaceuticals Ltd, India) were used. The same doses of erythromycin and roxithromycin were used as it was done in a previous study ${ }^{6}$, whereas the dose of ibuprofen was calculated from the average human doses using the body surface area conversion chart ${ }^{14}$. Erythromycin (40 $\mathrm{mg} / \mathrm{kg})$, roxithromycin $(20 \mathrm{mg} / \mathrm{kg})$ and ibuprofen $(100 \mathrm{mg} / \mathrm{kg})$ were mixed in $2 \%$ gum acacia and were administered orally.

\section{Experimental animals:}

Adult Wistar rats $(200 \pm 50 \mathrm{gms})$ of either sex with age $>6$ weeks were used. These animals were housed in polypropylene cages under standard laboratory conditions in a well ventilated room $\&$ fed on standard pellet diet. The animals had free access to diet \& water except at the time of experiment. They were placed in clean, neatly labelled cages containing 3 rats in each cage. The floor of the cages were stacked with grain husk which was replaced every second day. The animals were inspected frequently to rule out infections. In each cage the animals were identified by marking them with picric acid.

The Randomized, Prospective, Active placebo controlled study was conducted in the Department of Pharmacology, Grant Medical College \& Sir J.J. Group of hospitals, Mumbai, after approval from the institutional animal ethics committee.

\section{Study Groups:}

The rats were placed in 6 groups (G1-G6) containing 6 rats each. G1 was the control group and received only the vehicle (1 $\mathrm{ml}$ of $2 \%$ gum acacia); G2 was the standard group receiving Ibuprofen; G3 and G4 received roxithromycin and erythromycin respectively, and G5 and G6 received ibuprofen in addition to erythromycin and roxithromycin respectively.

\section{Interventions:}

Anti-inflammatory activity was evaluated by carrageenan-induced rat paw edema model described by Winter et al ${ }^{15}$ using a conventional mercury plethysmograph. The study drugs were given orally as a single dose one hour before administering 0.1 $\mathrm{ml}$ of $1 \%(\mathrm{w} / \mathrm{v})$ solution of carrageenan in normal saline into plantar region of right hind paw. Paw volume was measured as displacement of mercury column on the plethysmograph and was expressed in mm; the readings were taken at baseline and at hourly intervals up to 6 hours after administering carrageenan. Edema was measured as change in paw volume from baseline. Edema in the control group was taken as $100 \%$. Anti-inflammatory activity was calculated as percentage inhibition of edema using the formula $\%$ inhibition $=(\mathrm{C}-\mathrm{T}) / \mathrm{Cx} 100$ [where $\mathrm{C}=\mathrm{Control}$ edema; $\mathrm{T}=$ Test edema].

Analgesic activity was evaluated by radiant heat tail-flick latency method described by D`Armour and Smith ${ }^{16}$ and modified by Davies et $\mathrm{al}^{17}$. The strength of current passing through the nicrome wire of the analgesiometer (Inco, India) was kept constant at 5 amperes. After an initial screening phase, the suitable rats were given the test drugs orally, and the reaction time, that is the time taken by the rat to flick its tail in response to radiant heat issuing from the analgesiometer was measured at 30,60 and 120 minutes.

\section{Statistical analysis:}

Significance of difference for increase in tail-flick latency within the group was analyzed by Repeated Measure ANOVA followed by Tukey's Multiple Comparison test. Between the groups analysis was done by One-way ANOVA followed by Tukey's Multiple Comparison test. $\mathrm{P}$ value of $<0.05$ was considered significant. Statistical analysis was done using the statistical package 'Graphpad Instat 3' software (San Diego, California, USA).

\section{Results:}

\section{(I)Anti-inflammatory Evaluation (Table 1)}

Paw volumes at baseline in all the treatment groups were comparable to each other ( $\mathrm{p}>0.05)$. Paw volume in Ibuprofen, Roxithromycin, Erythromycin and combination groups, was significantly less at all time points as compared to control group $(\mathrm{p}<0.001)$. When these groups were compared with each other, there was not any significant difference at any time point ( $>0.05)$. Mean increase in paw volume at the end of 6 hours in the control group was $42 \pm 2.73 \mathrm{~mm}$. This was considered as $100 \%$ edema. Percentage inhibition of edema was $83.73 \%$ in the Ibuprofen group. It was highest in Ibuprofen + Roxithromycin group $(84.13 \%)$ and least in

Erythromycin group (73.02\%). 
Table 1: Comparison of Paw volume in the treatment groups at different time points

\begin{tabular}{|c|c|c|c|c|c|c|c|c|c|}
\hline \multirow{2}{*}{ Group/ Drug } & \multicolumn{7}{|c|}{ Paw Volume (Mean \pm SEM) ${ }^{\#}$} & \multirow{2}{*}{$\begin{array}{c}\text { Mean } \\
\text { increase } \\
\text { in paw } \\
\text { volume }\end{array}$} & \multirow{2}{*}{$\begin{array}{c}\text { Percentage } \\
\text { Inhibition (\%) }\end{array}$} \\
\hline & Baseline & $1 \mathrm{hr}$ & $2 \mathrm{hr}$ & $3 h \mathbf{r}$ & $4 h \mathbf{h r}$ & $5 \mathrm{hr}$ & $6 h r$ & & \\
\hline Control & $\begin{array}{c}36.33 \pm \\
2.98\end{array}$ & $\begin{array}{c}54.33 \pm \\
4.72\end{array}$ & $63.00 \pm 4.9$ & $70.00 \pm 5.14$ & $\begin{array}{c}75.00 \pm \\
5.18\end{array}$ & $\begin{array}{c}77.33 \pm \\
5.41\end{array}$ & $78.33 \pm 5.33$ & $\begin{array}{c}42.00 \pm \\
2.73\end{array}$ & -- \\
\hline $\begin{array}{l}\text { Ibuprofen } \\
(100 \mathrm{mg} / \mathrm{kg})\end{array}$ & $\begin{array}{c}35.83 \pm \\
1.80\end{array}$ & $\begin{array}{l}38.83 \pm \\
1.70 * *\end{array}$ & $\begin{array}{l}40.00 \pm \\
1.63 * * *\end{array}$ & $\begin{array}{l}41.67 \pm \\
1.82 * * *\end{array}$ & $\begin{array}{l}42.17 \pm \\
1.83 * * *\end{array}$ & $\begin{array}{l}43.00 \pm \\
1.88 * * *\end{array}$ & $\begin{array}{l}42.67 \pm \\
1.86 * * *\end{array}$ & $\begin{array}{c}6.83 \pm \\
1.01\end{array}$ & 83.73 \\
\hline $\begin{array}{l}\text { Roxithromycin } \\
(20 \mathrm{mg} / \mathrm{kg})\end{array}$ & $\begin{array}{c}38.17 \pm \\
2.37\end{array}$ & $\begin{array}{c}41.17 \pm \\
2.36^{*}\end{array}$ & $\begin{array}{l}43.00 \pm \\
2.25^{* *}\end{array}$ & $\begin{array}{l}45.67 \pm \\
2.17 * * *\end{array}$ & $\begin{array}{l}46.50 \pm \\
2.17 * * *\end{array}$ & $\begin{array}{l}47.33 \pm \\
2.03 * * *\end{array}$ & $\begin{array}{l}47.67 \pm \\
1.94 * * *\end{array}$ & $\begin{array}{c}9.50 \pm \\
0.99\end{array}$ & 77.38 \\
\hline $\begin{array}{l}\text { Erythromycin } \\
(40 \mathrm{mg} / \mathrm{kg})\end{array}$ & $\begin{array}{c}35.00 \pm \\
2.45\end{array}$ & $\begin{array}{c}39.50 \pm \\
2.69 *\end{array}$ & $\begin{array}{l}41.83 \pm \\
2.77 * *\end{array}$ & $\begin{array}{l}43.83 \pm \\
2.53 * * *\end{array}$ & $\begin{array}{l}45.33 \pm \\
2.39 * * *\end{array}$ & $\begin{array}{l}46.00 \pm \\
2.16 * * *\end{array}$ & $\begin{array}{l}46.33 \pm \\
2.09 * * *\end{array}$ & $\begin{array}{c}11.33 \pm \\
0.95\end{array}$ & 73.02 \\
\hline $\begin{array}{l}\text { Ibuprofen } \\
(100 \mathrm{mg} / \mathrm{kg})+ \\
\text { Roxithromycin } \\
(20 \mathrm{mg} / \mathrm{kg})\end{array}$ & $\begin{array}{c}38.50 \pm \\
2.53\end{array}$ & $\begin{array}{c}41.33 \pm \\
2.44^{*}\end{array}$ & $\begin{array}{l}43.00 \pm \\
2.50 * * *\end{array}$ & $\begin{array}{l}43.67 \pm \\
2.47 * * *\end{array}$ & $\begin{array}{l}44.67 \pm \\
2.40 * * *\end{array}$ & $\begin{array}{l}45.33 \pm \\
2.33 * * *\end{array}$ & $\begin{array}{l}45.17 \pm \\
2.36 * * *\end{array}$ & $\begin{array}{c}6.67 \pm \\
0.42\end{array}$ & 84.13 \\
\hline $\begin{array}{l}\text { Ibuprofen } \\
(100 \mathrm{mg} / \mathrm{kg})+ \\
\text { Erythromycin } \\
(40 \mathrm{mg} / \mathrm{kg})\end{array}$ & $\begin{array}{c}36.17 \pm \\
2.93\end{array}$ & $\begin{array}{l}38.83 \pm \\
2.68 * *\end{array}$ & $\begin{array}{l}40.33 \pm \\
2.50 * * *\end{array}$ & $\begin{array}{l}41.67 \pm \\
2.39 * * *\end{array}$ & $\begin{array}{l}42.83 \pm \\
2.45 * * *\end{array}$ & $\begin{array}{l}43.50 \pm \\
2.39 * * *\end{array}$ & $\begin{array}{l}43.50 \pm \\
2.38 * *\end{array}$ & $\begin{array}{c}7.33 \pm \\
0.61\end{array}$ & 82.54 \\
\hline
\end{tabular}

\section{(II) Analgesic Evaluation (Table 2)}

Tail-flick latencies in the Roxithromycin and Erythromycin group at 30, 60 and 120 min were non-significant as compared to control group at corresponding time points ( $>$ > 0.05). Whereas; in the Ibuprofen, Ibuprofen + Roxithromycin and Ibuprofen + Erythromycin group, tail-flick latencies were significantly different from that of control group at all time points. Roxithromycin and Erythromycin groups produced significantly different tail-flick latencies as compared to Ibuprofen group $(\mathrm{p}<0.001)$. 
Table 2: Comparison of Tail-flick latency in the treatment groups

\begin{tabular}{|c|c|c|c|c|}
\hline \multirow{2}{*}{ Group/ Drug } & \multicolumn{4}{|c|}{ Tail-flick latency in sec (Mean \pm SEM) } \\
\hline & 0 min & $30 \mathrm{~min}$ & $60 \mathrm{~min}$ & $120 \mathrm{~min}$ \\
\hline Control & $3.40 \pm 0.02$ & $3.41 \pm 0.02$ & $3.42 \pm 0.02$ & $3.42 \pm 0.01$ \\
\hline $\begin{array}{l}\text { Ibuprofen } \\
(100 \mathrm{mg} / \mathrm{kg})\end{array}$ & $3.46 \pm 0.03$ & $4.11 \pm 0.03 * * *$ & $4.61 \pm 0.02 * * *$ & $4.95 \pm 0.03 * * *$ \\
\hline $\begin{array}{l}\text { Roxithromycin } \\
(20 \mathrm{mg} / \mathrm{kg})\end{array}$ & $3.44 \pm 0.02$ & $3.47 \pm 0.02$ & $3.50 \pm 0.02$ & $3.52 \pm 0.02$ \\
\hline $\begin{array}{l}\text { Erythromycin } \\
(40 \mathrm{mg} / \mathrm{kg})\end{array}$ & $3.37 \pm 0.02$ & $3.38 \pm 0.03$ & $3.42 \pm 0.02$ & $3.45 \pm 0.03$ \\
\hline $\begin{array}{l}\text { Ibuprofen } \\
(100 \mathrm{mg} / \mathrm{kg})+ \\
\text { Roxithromycin } \\
(20 \mathrm{mg} / \mathrm{kg})\end{array}$ & $3.36 \pm 0.02$ & $4.20 \pm 0.03 * * *$ & $4.66 \pm 0.05^{* * *}$ & $4.89 \pm 0.05^{* * *}$ \\
\hline $\begin{array}{l}\text { Ibuprofen } \\
(100 \mathrm{mg} / \mathrm{kg})+ \\
\text { Erythromycin } \\
(40 \mathrm{mg} / \mathrm{kg}\end{array}$ & $3.47 \pm 0.02$ & $4.06 \pm 0.02 * * *$ & $4.45 \pm 0.02 * * *$ & $4.85 \pm 0.02 * * *$ \\
\hline
\end{tabular}




\section{Discussion:}

After a long history of anti-infective therapeutic use, macrolide antibiotics have not yet given up all their secrets. Interest in their therapeutic potential in inflammatory diseases (possibly including non-infectious diseases) has generated abundant fundamental research and therapeutic trials worldwide ${ }^{18}$.

\section{(I) Anti-inflammatory evaluation}

Roxithromycin $(20 \mathrm{mg} / \mathrm{kg})$ and Erythromycin $(40 \mathrm{mg} / \mathrm{kg})$ produced statistically significant percentage inhibition in carrageenan-induced edema $(77.38 \%$ and $73.02 \%$ respectively, Table 1$)$ in comparison with control $(\mathrm{p}<0.01)$. By these results, Roxithromycin appears to be more effective than Erythromycin in reducing inflammatory reaction. Our results are consistent with the results of Ianaro et $\mathrm{al}^{6}$. Also, macrolides exhibited less anti-inflammatory activity than ibuprofen; this is similar to the findings of Agen $\mathrm{C}$ et $\mathrm{al}^{19}$. Change in paw volume in the combination groups (Ibuprofen $100 \mathrm{mg} / \mathrm{kg}+$ Roxithromycin $20 \mathrm{mg} / \mathrm{kg}$ and Ibuprofen $100 \mathrm{mg} / \mathrm{kg}+$ Erythromycin $20 \mathrm{mg} / \mathrm{kg}$ ) was not significantly different from that of Ibuprofen $(\mathrm{p}>0.05)$; hence it appears that there is no additional anti-inflammatory activity in the combination groups.

The various proposed mechanisms for the anti-inflammatory activity of macrolides include accumulation of macrolides and subsequent impairment of oxidative burst within Polymorphonuclear leucocytes $(\mathrm{PMNs})^{20,}{ }^{21}$, and interference with production of cytokines like PGF $1 \alpha, \mathrm{NO} \neg 2$, and TNF - $\alpha$, IL- $1 \mathrm{~b}$, and IL- $6^{6}$. Both of these mechanisms are not dependent on direct inhibition of COX-2.

Since ibuprofen is a known inhibitor of COX-2, the combination of two anti-inflammatory drugs acting via different mechanisms should have caused an increased effect. This was not seen in our study. This may be explained by the similarity in final targets in the inflammatory pathway at which macrolides and NSAIDs appear to act. Ibuprofen, by inhibiting COX, reduces the production of $\mathrm{PGs}^{22}$, thereby causing vasodilation ${ }^{23}$. On the other hand, macrolides inhibit the endothelial injury caused by oxygen-derived free radicals, and thus prevent an increase in vascular permeability. Thus, both the drug groups are affecting hemodynamic component of inflammation, albeit through different routes, and additional anti-inflammatory effect may therefore have not been seen by their combination.

Though the role of macrolides in acute inflammation has been described by our study and numerous other studies mentioned above, their role in chronic inflammation is not clear-cut, with different studies providing contradictory evidence $^{19,24}$. The clinical reports of the beneficial effects of macrolides in inflammatory conditions, taken together with the results of our study, confirm the anti-inflammatory activity of Roxithromycin and Erythromycin. Although the antiinflammatory activity of macrolides is secondary to its anti-infective capacity, well planned studies may further disclose the role of macrolides in chronic inflammation, and in the treatment of asthma, bronchiectasis and osteomyelitis.

\section{(II) Analgesic Evaluation}

Macrolides act by inhibiting hyperalgesic mediators such as $\mathrm{PGE}_{2}$, which are predominantly involved in peripheral pain pathways. Though acetic acid induced writhing would have been a better model for analyzing analgesic properties of macrolides, this method was not chosen because erythromycin itself is known to induce writhing in rats ${ }^{25}$. On the other hand, the rat tail flick method is generally used for centrally acting analgesics such as morphine. A reduction of peripheral nociceptive input to the central nervous system could also reduce central sensitization ${ }^{26}$. Macrolides may act as peripherally acting analgesics and may also lead to reduction of central sensitization. Hence, it was decided to evaluate analgesic activity of macrolides by radiant heat tail-flick latency test.

In our study, it was observed that although both roxithromycin $20 \mathrm{mg} / \mathrm{kg}$ and erythromycin $40 \mathrm{mg} / \mathrm{kg} \mathrm{produced}$ statistically significant increase in tail-flick latency at $60 \mathrm{~min}$ and $120 \mathrm{~min}$ as compared to $0 \mathrm{~min}(\mathrm{p}<0.001)$, this increase was non-significant when compared to control group ( $p>0.05$ ). Additionally, when Ibuprofen was compared with Roxithromycin and Erythromycin, there was significant difference in tail-flick latencies at all time points ( $<<0.001)$. The combination of ibuprofen with macrolides failed to show any statistically significant improvement over latency when compared to ibuprofen alone $(\mathrm{p}>0.05)$ (Table 2). These results indicate that though the macrolides increases tail-flick latency, their efficacy does not reach up to efficacy of established analgesic drugs, and that the macrolides also do not have the property to add to the analgesic effect of ibuprofen.

Pain that accompanies inflammation and tissue injury probably results from local stimulation of pain fibres by numerous chemical mediators, including bradykinin, cytokines such as TNF- $\square$, IL-1, and IL-8, prostaglandins, specially $\mathrm{PGE}_{2}$ and $\mathrm{PGF}_{2 \alpha}$, neuropeptides such as substance $\mathrm{P}$ and calcitonin gene-related peptide (CGRP). Macrolides are known to inhibit the production of only some of the above mentioned factors, such as, PGE 2 , TNF- $\square$, IL- $1^{6}$. As a result, there may be unopposed stimulation of peripheral nociceptors by other inflammatory mediators. This might be the reason for the macrolides not showing significant analgesic activity. 
Analgesic evaluation of macrolides was done by radiant heat tail-flick method which is less sensitive to peripherally acting analgesic drugs ${ }^{27}$. This may also be the reason for the weak analgesic effect of macrolides.

The fact that the macrolides failed to show additional analgesic activity in combination with ibuprofen can be explained by the similarity in the mechanism of actions i.e. they is affecting the similar pathways of inflammation and pain.

Results of our study suggest tendency of Roxithromycin and Erythromycin towards analgesic potential, and warrant additional evaluation of the same by other models. If found to have analgesic potential, then the macrolides will be of additional benefit in cases like recurrent osteomyelitis and post-operative patients by reducing the dose of NSAIDs for achieving desired analgesia.

To summarize, Roxithromycin $20 \mathrm{mg} / \mathrm{kg}$ and Erythromycin $40 \mathrm{mg} / \mathrm{kg}$ have anti-inflammatory activity in animal model and Roxithromycin appears to be more effective than Erythromycin. However, combination of Ibuprofen and Roxithromycin or Erythromycin does not have any additional anti-inflammatory effect compared to Ibuprofen alone. The macrolides also have shown a tendency towards analgesic potential although statistically less significant than conventional analgesics like Ibuprofen. However, combination of Ibuprofen and Roxithromycin or Erythromycin does not have additional analgesic activity as compared to Ibuprofen alone. Source of Support: Self-funded. Conflicts of Interest: None

\section{Bibliography:}

1. Brisson-Noël A, Trieu-Cuot P, Courvalin P. Mechanism of action of spiramycin and other macrolides. J Antimicrob Chemother 1988 Jul;22 Suppl B:13-23.

2. Hunaiti AA, Kolattukudy PE. Source of methylmalonyl-coenzyme A for erythromycin synthesis: methylmalonyl-coenzyme A mutase from Streptomyces erythreus. Antimicrob Agents Chemother 1984 Feb;25(2):173-8.

3. Washington JA 2nd, Wilson WR. Erythromycin: a microbial and clinical perspective after 30 years of clinical use (2). Mayo Clin Proc 1985 Apr; 60(4): 271-8.

4. Wood MJ. Some may be improvements on Erythromycin. BMJ 1991 Sept; 303: 594-5.

5. Satoskar SR, Bhandarkar SD, Rege NN. Penicillins and other antibiotics effective against Gram positive organisms. In: Pharmacology and Pharmacotherapeutics. 20th ed. Mumbai: Popular prakashan; 2008: p. 6645 .

6. Ianaro A, Ialenti A, Maffia P, Sautebin L, Rombolà L, Carnuccio R, Iuvone T, D'Acquisto F, Di Rosa M. Anti-inflammatory activity of macrolide antibiotics. J Pharmacol Exp Ther 2000 Jan; 292(1): 156-63.

7. Plewig G, Schöpf E. Anti-inflammatory effects of antimicrobial agents: an in vivo study. J Invest Dermatol 1975 Dec;65(6):532-6.

8. Schilling F, Wagner AD. Azithromycin: an anti-inflammatory effect in chronic recurrent multifocal osteomyelitis? A preliminary report [Article in German] Z Rheumatol 2000 Oct;59(5):352-3.

9. Wallwork B, Coman W, Mackay-Sim A, Greiff L, Cervin A. A double-blind, randomized, placebo-controlled trial of macrolide in the treatment of chronic rhinosinusitis. Laryngoscope 2006 Feb; 116(2):189-93.

10. Cazzola M, Matera MG, Blasi F. Macrolide and occult infection in asthma. Curr Opin Pulm Med 2004 Jan;10(1):7-14.

11. Maselli DJ, Adams S, Peters J. The role of anti-infectives in the treatment of refractory asthma. Ther Adv Respir Dis 2011 Apr 1. [Epub ahead of print]

12. Vaz AP, Morais A, Melo N, Caetano Mota P, Souto Moura C, Amorim A.Azithromycin as an adjuvant therapy in cryptogenic organizing pneumonia. Rev Port Pneumol 2011 Jun 6. [Epub ahead of print]

13. Richeldi L, Ferrara G, Fabbri LM, Lasserson TJ, Gibson PG. Macrolides for chronic asthma. Cochrane Database Syst Rev 2005 Oct 19;(4):CD002997.

14. Ghosh MN. Toxicity studies. Fundamentals of Experimental Pharmacology 3rd ed. Kolkata, Hilton and Compony-2005. Page176-83.

15. Winter CA, Risley EA, Nuss GW. Carrageenan-induced oedema in hind paw of the rat as an assay for antiinflammatory drugs. Proc Soc Exp Biol Med 1962; 111: 544-547

16. D'Armour FE, Smith DL. A method for determining loss of pain sensation. J Pharmacol Exp Ther 1941; 72: 74-79

17. Davies OL, Raventós J, Walpole AL. A method for the evaluation of analgesic activity using rats. Br J Pharmacol 1946; 1: 255-64

18. Labro MT. Macrolide antibiotics: current and future uses. Expert opinion on pharmacotherapy 2004 March; 5(3): 541-50

19. Agen C, Danesi R, Blandizzi C, Costa M, Stacchini B, Favini P et al. Macrolide antibiotics as antiinflammatory agents: Roxithromycin in an unexpected role. Agents \& Actions 1993 Jan; 38(1-2): 85-90. 
20. Labro MT, Benna JE, Babin-Chevaye C. Comparison of the in-vitro effect of several macrolides on the oxidative burst of human neutrophils. Journal of Antimicrobial Chemotherapy 1989; 24: 561-72

21. Martina B, Zeljko K, Vesna M, Vesna E, Michael J. Cellular Uptake and Efflux of Azithromycin, Erythromycin, Clarithromycin, Telithromycin, and Cethromycin. Antimicrobial Agents and Chemotherapy 2005 June: 2372-77.

22. Burke A, Smyth E, FitzGerald GA. Analgesic-Antipyretic Agents; Pharmacotherapy of Gout. In: Laurence LB, editor. Goodman \& Gilman's The Pharmacological Basis of Therapeutics 11th edition. New York: McGraw Hill Publications; 2006. p.698.

23. Vinay K, Abul KA, Nelson F. Acute and Chronic inflammation. In: Robbins and Cotran editors. Pathologic Basis of Disease, 7th edition. 2005; New Delhi: Elsevier: P. 47-86.

24. Scaglione F, Rossoni G. Comparative anti-inflammatory effects of Roxithromycin, azithromycin and clarithromycin. Journal of Antimicrobial Chemotherapy 1998; 41: 47-50.

25. Vinadrell P, Planas J, Torralba A. Inhibition of Erythromycin-lactobionate induced writhing by analgesic drugs. Farmaco [prat] 1980 Mar; 35(3): 133-40.

26. Milan MJ. The induction of pain: An Integrative Review. Progressive Neurobiology 1999; 57: 1-164.

27. Vogel HG. Analgesic, Anti-inflammatory and anti-pyretic activity. In: Drug Discovery and Evaluation, 2nd edition. New York: Springer Publication; 2002. p.751-760. 